\title{
Addressing Tectonic and Metamorphic Controversy in the Pakistan Himalaya
}

\author{
Joseph A Dipietro \\ University of Southern Indiana, Dept. of Geology, 8600 University Blvd., Evansville, IN 47712, USA \\ E-mail:dipietro@usi.edu
}

Some of the more controversial or less agreed upon aspects of the Pakistan Himalaya include the absolute age (or ages) of metamorphism, the cause of metamorphism, the location (or existence) of the MCT, the existence of the STDS or STDSequivalent extensional faulting, the correlation of stratigraphy and tectonostratigraphic zones, and transport direction. In this paper I address some of these in an attempt to summarize the geology of the Pakistan Himalaya.

It must first be pointed out that the geology is not perfectly continuous across Pakistan. There is a discontinuity located along the western margin of the Hazara syntaxis. It was shown as a major fault by Wadia (1931) who bent it northeastward and extended it all the way to the Kohistan arc. Part of this fault was mapped by Bossart et al. (1986) as the 'mylonite zone.' Later workers ignored Wadia's interpretation and, within about $5 \mathrm{~km}$ of the Kohistan arc, bent the fault eastward to connect with the Batal thrust, referring to its entire trace as the MCT. DiPietro and Pogue (2004) argued in support of Wadia's interpretation and referred to it as the Jhelum-Balakot fault. This fault effectively divides the Pakistan Himalaya into an eastern half (the Naran region), and a western half (the Western Hinterland) (Figure 1).

All known occurrences of eclogite are in the Naran region on the upper plate of the Batal thrust. According to DiPietro and Pogue (2004), the Batal thrust is truncated at the Jhelum-Balakot fault, offset southward, and reappears in the Western Hinterland as the Banna thrust which, itself, terminates against the Indus suture zone on the east side of the Indus Syntaxis. Irregardless of whether the Batal and Banna faults correlate, the relationships indicate that nearly the entire Western Hinterland is structurally below the Batal thrust. In the Naran region, the Batal thrust is interpreted as extending eastward into the mountains and metamorphic rocks south of Nanga Parbat. This is not the MCT.

An important distinction must also be made between thrust faults that underlie the Indus Suture Zone, and the Kohistan fault which underlies the Kohistan arc. Foliation in graphic schists at the top of the Indian plate are continuous with chlorite and talc schists that form the matrix rock in the Indus Suture Zone. Additionally, the suture zone is folded about late-metamorphic F3 folds. This implies that Indian plate rocks were underthrust beneath the suture zone prior to and/or during regional foliationforming metamorphism. The Kohistan fault, by contrast, truncates foliation in both the suture zone and Indian plate and truncates the late-metamorphic F3 folds that deform the suture zone. The fault cuts across strike such that suture zone rock is absent in the Indus Syntaxis region and in the area north of the Malakand fault slice. The assumption that there was simultaneous transport and emplacement of the Indus Suture Zone and the Kohistan arc is incorrect. Thrusting of Kohistan played no role in the prograde metamorphism of the Western Hinterland.
The only major thrust faults in the Western Hinterland are the Banna thrust in the east, and the Malakand thrust in the west. Both are syn-metamorphic and both are folded by latemetamorphic F3 folds. They appear to have been active during activity in the suture zone. Significant shortening may have been accommodated along these thrust faults but neither extend across the hinterland. Both truncate against the suture zone or Kohistan fault. The remainder of the Western Hinterland appears to have acted as a single coherent block throughout metamorphism that remained largely autochthonous prior to middle Miocene displacement along the Panjal-Khairabad thrust. This is indicated by Permian and Mesozoic stratigraphic rock units that can be traced continuously across the hinterland. Wadia (1934) mapped what he referred to as a Paleozoic unconformity below Permian Panjal Volcanics in the region surrounding the Kashmir Basin. He showed that the age of rocks directly below the unconformity vary considerably from middle Paleozoic to what are probably Lower Proterozoic. Wadia implicitly showed that the Kashmir region contains a coherent stratigraphy of (probable) Early Proterozoic age to Mesozoic age that would later correlate with parts of the Lesser Himalayan, Greater Himalayan, and Tethyan Himalayan sequence. This stratigraphy is likely present in the Naran and Nanga Parbat regions and is unquestionably present in the Western Hinterland. Intrusive rock, such as Lesser Himalayan, Ulleri-equivalent, Kotla orthogneiss, and Greater Himalayan 500 Ma orthogneiss, are also present. The Panjal-Khairabad thrust forms the southern boundary of the Western Hinterland and is considered to be the western continuation of the MCT. Greater Himalayan stratigraphy, and $500 \mathrm{Ma}$ orthogneiss, are both absent south of the thrust. This fault, however, is post-metamorphic, appears to have initiated later than the Central Himalayan MCT and does not show nearly the displacement.

It has been assumed that transport of both the Indus Suture Zone and the Kohistan arc was in a southward direction presumably because both are oriented roughly east-west, faulting in the Pakistan foreland is toward the south, and the most obvious lineations within the western Hinterland are oriented generally north-south. Detailed analysis does not support this conclusion. The most widespread lineation is a north-south crenulation of the regional foliation associated with late-metamorphic F3 folds. These folds deform the suture zone and are truncated by the Kohistan fault. They are not valid indicators of transport direction for either tectonic terrane. South-directed thrusting in the foreland also is not relevant because it is younger than displacement on the Kohistan fault. Syn-metamorphic transport of the Indus Suture zone and Banna thrust zone is inferred to be toward the SW or WSW based on westward vergence of large-scale syn-metamorphic F1/F2 folds and on stretching lineations which, although variable, are dominantly oriented NNE-SSW. The Kohistan arc was transported in a different 
direction. Kinematic indicators along the fault consistently show thrust and dextral strike-slip displacement with ESE to E-directed transport. This is consistent with the Naran region where early SWtransport and then SE-transport is also reported (Greco et al. 1989). The southern termination of the Kohistan fault in the western part of the hinterland is interpreted to be a right-slip sidewall ramp such that the Kohistan arc never advanced much farther south on the Indian plate than its present position. This fault likely remained active until late Oligocene or early Miocene when south vergence first began in the hinterland. Although active in the foreland since middle Miocene, south vergence presently is not active in the hinterland. The 2005 Kashmir earthquake revealed the Bagh blind fault with southwestward transport that cuts across all earlier structures.

The Kohistan fault has been interpreted as a major extensional fault equivalent with the STDS even though it is located north of the Indus Suture Zone (not within the Indian plate). The evidence, however, is not convincing. Detailed analysis of the fault zone at three locations in the Western Hinterland provides evidence that long-term and final displacement was in the form of thrusting or dextral strike-slip faulting. The Kohistan fault in the Naran and Nanga Parbat regions has been overprinted by the Balakot, Diamir, and Raikot fault zones. All three faults are north to northwest-striking with southeast or east-side-up reverse displacement that places Indian plate rocks structurally above the Kohistan arc. None appear to be extensional.

The age of metamorphism in the Western Hinterland is poorly constrained. Flat hornblende Ar-Ar spectra vary from 67 to $31 \mathrm{Ma}$ with additional dates circa $175 \mathrm{Ma}$ and $1900 \mathrm{Ma}$ (Treloar and Rex 1990). Zircons from the post-metamorphic Malakand granite recently gave a well defined LA-ICPMS age of $32.7 \pm 0.5 \mathrm{Ma}$ (unpublished data). Smith et al. (1994) reported a zircon rim SHRIMP age of $47 \pm 3 \mathrm{Ma}$ from the same granite. The disparate ages, and the description that their rock is deformed, suggests that Smith et al. (1994) may have dated a metamorphic overgrowth from the nearby Chakdarra orthogneiss. Zircons from another post-metamorphic intrusion, the Khar Diorite, gave a well defined LA-ICPMS age of $48.1 \pm 0.8 \mathrm{Ma}$ (unpublished data). This rock intrudes the suture zone (not the Indian plate) near Afghanistan at the structural top of the metamorphic pile. Collectively, the Western Hinterland has yielded detrital zircons from circa 2200 to $2930 \mathrm{Ma}$; igneous zircons circa 1850, 825, 500, 270, 48 (within the suture zone), and $33 \mathrm{Ma}$; metamorphic zircons circa 2175, 262, and $89 \mathrm{Ma}$; and possible metamorphic zircon overgrowths circa 47 and $40 \mathrm{Ma}$ (DiPietro and Isachsen 2001). These data suggest only that metamorphism was active during middle Eocene (49-37 Ma) and that there may have been multiple metamorphic episodes during late Mesozoic/Cenozoic and earlier. This is broadly consistent with ages obtained in the Naran region. More work is required to constrain the timing of metamorphism relative to fabric development.

In summary, the cause of metamorphism in the Western Hinterland is underthrusting beneath the Indus Suture Zone prior to, and/or during, the middle Eocene. The Kohistan arc arrived post-metamorphic, after development of F3 folds that deform the suture zone. Neither produced south-verging structures in the Western Hinterland. The Western Hinterland consists of conformable Lesser, Greater, and Tethyan stratigraphy that, with the exception of the Banna and Malakand thrusts, remained coherent throughout deformation.

References

Bossart P, D Dietrich, A Greco, R Ottiger and JG Ramsay. 1988. The tectonic structure of the Hazara-Kashmir syntaxis, Southern Himalayas, Pakistan. Tectonics 7: 273-297

DiPietro JA and CE Isachsen. 2001. U-Pb zircon ages from the Indian Plate in northwest Pakistan and their significance to Himalayan and pre-Himalayan geologic history. Tectonics 20: 510-525

DiPietro JA and KR Pogue. 2004. Tectonostratigraphic subdivisions of the Himalaya: A view from the west. Tectonics 23: TC5001 doi:10.1029/ 2003TC001554 20

Greco A, G Martinotti, K Papritz, JG Ramsay and R Rey. 1989. The crystalline rocks of the Kaghan Valley (NE-Pakistan). Eclogae Geologicae Helvetiae 82: 629-653

Smith HA, CP Chamberlain and PK Zeitler. 1994. Timing and duration of Himalayan metamorphism within the Indian plate, northwest Himalaya, Pakistan. Journal of Geology 102: 493-508

Treloar PJ and DC Rex. 1990. Cooling and uplift histories of the crystalline thrust stack of the Indian plate internal zones west of Nanga Parbat, Pakistan Himalaya. Tectonophysics 180: 323-349

Wadia DN. 1931. The syntaxis of the northwest Himalaya: Its rocks, tectonics and orogeny. Records of the Geological Survey of India 65: 189-220

Wadia DN. 1934. The Cambrian-Trias sequence of northwest Kashmir (parts of the Mazaffarabad and Baramula District). Records of the Geological Survey of India 68: 121-146

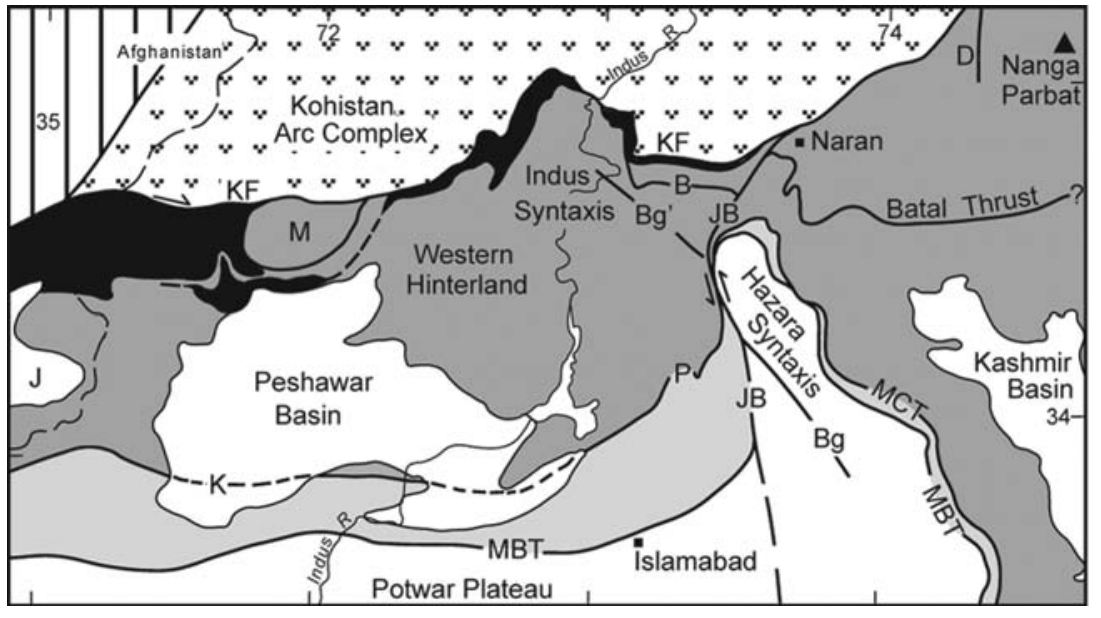

FIGURE 1. Simplified map of the Pakistan Himalaya. Black areas are lenses of suture zone rock. B-Banna Thrust; Bg-Bagh Fault; Bg'-Bagh Blind Fault; D-Diamir Fault; J-Jalalabad Basin; JB-JhelumBalakot Fault; K-Khairabad thrust; KF-Kohistan Fault; M-Malakand Fault Slice; MBT-Main Boundary Thrust; MCT-Main Central Thrust; P-Panjal thrust. 